Article

\title{
Evaluating Permeable Clay Brick Pavement for Pollutant Removal from Varying Strength Stormwaters in Arid Regions
}

\author{
Md. Shafiquzzaman 1,*(D), Saad Mohammed A. Alqarawi ${ }^{1}$, Husnain Haider 1ㅁ, Md. Rafiquzzaman ${ }^{2}$, \\ Meshal Almoshaogeh ${ }^{1}$ (D) Fawaz Alharbi ${ }^{1}$ (D) and Yassine El-Ghoul ${ }^{3}$ (D)
}

1 Department of Civil Engineering, College of Engineering, Qassim University, Buraidah 51452, Saudi Arabia; eng.saad177@gmail.com (S.M.A.A.); husnain@qec.edu.sa (H.H.); m.moshaogeh@qec.edu.sa (M.A.); f.a@qec.edu.sa (F.A.)

2 Department of Industrial Engineering and Management, Khulna University of Engineering and Technology, Khulna 9203, Bangladesh; rafiq123@iem.kuet.ac.bd

3 Department of Chemistry, College of Science, Qassim University, Buraidah 51452, Saudi Arabia; y.elghoul@qu.edu.sa

* Correspondence: m.uzzaman@qu.edu.sa or shafiq@qec.edu.sa

Citation: Shafiquzzaman, M.; Alqarawi, S.M.A.; Haider, H.; Rafiquzzaman, M.; Almoshaogeh, M.; Alharbi, F.; El-Ghoul, Y. Evaluating Permeable Clay Brick Pavement for Pollutant Removal from Varying Strength Stormwaters in Arid Regions. Water 2022, 14, 491. https://doi.org/10.3390/ w14030491

Academic Editors: Yung-Tse Hung, Hamidi Abdul Aziz, Issam

A. Al-Khatib, Rehab O.

Abdel Rahman and Tsuyoshi Imai

Received: 21 December 2021

Accepted: 2 February 2022

Published: 7 February 2022

Publisher's Note: MDPI stays neutral with regard to jurisdictional claims in published maps and institutional affiliations.

Copyright: (C) 2022 by the authors. Licensee MDPI, Basel, Switzerland. This article is an open access article distributed under the terms and conditions of the Creative Commons Attribution (CC BY) license (https:// creativecommons.org/licenses/by/ $4.0 /$ )

\begin{abstract}
Permeable pavement is a low impact development technology for stormwater (SW) runoff control and pollutant removal. The strength of SW depends on land use of the catchment, e.g., semi-urban vs. industrial. The performance (in terms of pollutants removal) of permeable clay bricks (PCB) has not been adequately assessed for SW of varying strengths. For using the permeable clay bricks as a pavement surface layer, the present research investigates its pollutant removal capacity through SW infiltration using a laboratory setup. SW samples of two different strengths, i.e., high polluted stormwater (HPSW) and less polluted stormwater (LPSW), were tested for a pavement system consisting of the clay brick layer on top of a coarse gravel support layer. The tests were performed at a rainfall intensity of $12.5 \mathrm{~mm} / \mathrm{h}$ (for a 10-year return period in Buraidah, Qassim) to evaluate the suitability of PCB for the arid and semi-arid regions. The experiments revealed that PCB became fully saturated and achieved a steady-state outflow condition after 10 min of rainfall. Irrespective of contamination level, the pollutant removal efficiency was found to be similar for both HPSW and LPSW. High TSS (>98\%) and turbidity (>99\%) removals were achieved for both strengths, while BOD5 (78.4\%) and COD (76.1\%) removals were moderate. Poor to moderate nutrient removal, $30.5 \%$ and $39.1 \%$ for total nitrogen (TN) and 34.7\% and 31.3\% for total phosphorus (TP), respectively for HPSW and LPSW, indicates an adsorptive removal of nutrients in the system. Heavy metal removal efficiency ranged from $6.7 \%$ to $94 \%$, with higher removals archived for Fe, Mn, Se, and $\mathrm{Pb}$. The study provides insights into the role of $\mathrm{PCB}$ as a surface layer in the permeable pavement for pollutant removal. The study also establishes the guidelines for the optimal permeable pavement design to deal with SW of varying contamination levels. Permeable clay bricks showed the potential to be used as a sustainable LID technology for arid regions.
\end{abstract}

Keywords: permeable clay bricks; stormwater; infiltration; pollutants removal; LID technology

\section{Introduction}

Urbanization around the globe has significantly reduced permeable surfaces, resulting in an increase in surface runoff rates and an allied decline in groundwater recharge. Urban stormwater (SW) runoff containing various pollutants eventually reaches out to surface water bodies, such as rivers, lakes, retention ponds, and natural drains. A typical SW runoff contains organics (BOD and COD), nutrients (phosphorus and nitrogen), hydrocarbons, oils, heavy metals, and emerging pollutants [1-4]. The presence of these pollutants in surface waters contaminates water sources, impacting human health and the ecological balance. Low impact development (LID) technology is a sustainable SW management approach, which includes bioswales, constructed wetlands, vegetated filter strips, sand 
filters, media filters, and permeable pavements (PPs) [5-7]. The bio-swales, constructed wetlands, and vegetated filter strips are low-cost techniques and can effectively minimize the runoff and pollutants using natural systems [5]. The media filter and sand filter are relatively recent LID techniques, which are capable of a moderate removal of particulate organics, nutrients, and heavy metals $(\mathrm{Cd}, \mathrm{Cu}, \mathrm{Pb}, \mathrm{Ni}, \mathrm{Cr}$, and $\mathrm{Zn})$ [6]. Rain gardens and bioswales effectively remove organic and inorganic contaminants $[1,8]$. Vegetated bio-retention systems are highly efficient in removing organic constituents and metals from SW runoff [9].

In the quest of attaining a sustainable pavement design using LID techniques, PPs have been widely used for SW management due to their unique characteristics for improving the runoff quality $[10,11]$. PPs are also capable of on-site SW infiltration without occupying the additional landscape of an urban setting, and they help in groundwater recharge [12]. Being an onsite infiltration process, PPs also decrease the SW drainage system cost [13]. Permeable concrete-based pavements, asphalt-based pavements, and permeable brick pavements are commonly used PPs in sidewalks, public squares, and car parks [14-16]. A permeable pavement generally consists of a layer of pavers at the top followed by base (soil or sand) and sub-base (gravel) layers [11]. These pavements function as a runoff storage reservoir and simultaneously filter various pollutants from SW runoff, e.g., total suspended solids (TSS), organic matter, turbidity, nutrients (e.g., nitrogen and phosphorus), heavy metals (e.g., $\mathrm{Cu}, \mathrm{Pb}$, and $\mathrm{Zn}$ ), and hydrocarbons [17-20].

Several mechanisms are involved in removing the pollutants during infiltration, such as adsorption, precipitation, rejection, and biological oxidation-reduction [21]. A previous study by Brown et al. [22] reported 90-96\% retention of TSS in two typical PPs, including porous asphalt and open-jointed paving blocks. Liu et al. [23] reported that the surface pavement layer plays a significant role in the removal of TSS, organics, and nutrients. Permeable ceramic bricks can effectively remove TSS (79.8\%) and TP $(71.2 \%)$ along with some chemical oxygen demand (COD) and total nitrogen (TN) removal from the runoff [18]. The performance of permeable pavement depends on several factors, such as rainfall intensity, pollutant concentration, and brick material $[19,24]$. A recent study reported that ceramic brick pavements performed better than concrete brick pavements for TN removal from SW runoff [25]

As a low-cost LID technique to mitigate the environmental impacts of runoff pollution, PPs have received particular attention for sustainable SW management [26]. Therefore, research efforts on quantitative performance evaluation need to be extended for structural stability, permeability, pollutant removal capability, and socioeconomic viability of PPs. Material properties and the pore size of the surface layer significantly affect the infiltration capability and water quality of runoff $[27,28]$. Li et al. [19] reported that shale brick more efficiently removes the pollutants from surface runoff as compared to other materials. Most of the past studies evaluated the properties of the surface layer for pollutant removal from SW. The effect of variations in SW quality on the PPs' performance needs to be further studied. Recently, Al Harbi et al. [29] used a mixture of clay soil and rice bran to develop a novel porous clay brick to apply as a permeable pavement surface layer. The unique materials and fabrication process of the brick can lead to a distinct performance in comparison with the existing permeable bricks.

The present research assessed the performance of the permeable clay bricks to apply it as a permeable pavement surface layer, developed by Al Harbi et al. [29], in terms of infiltration capacity and pollutant removal using a laboratory setting. The pollutant removal efficiency of the brick was evaluated for two different strengths of contaminated SW. This research will provide insights into the performance of permeable clay brick to accommodate the SW of varying strengths originating from different land uses. 


\section{Materials and Methods}

\subsection{Permeable Clay Bricks}

The bricks were manufactured by mixing the clay soil with rice bran at a ratio of $90 \%$ and $10 \%$ by weight. At this mixing ratio, the bricks achieved sufficient compressive strength and permeability coefficients, meeting the American society for testing and materials(ASTM) standards for pedestrian and light traffic [29]. Figure 1 briefly outlines the steps involved in the brick making procedure. In brief, a conventional clay brick making process was applied to manufacture the porous clay bricks. Before mixing, the soil and rice bran were sieved to $0.5 \mathrm{~mm}$ to make a homogeneous mixture. In the subsequent step, a suitable amount of water was added to make the dough with the desired plasticity and workability. The dough was then filled in a rectangular wooden mold $(100 \times 70 \times 70 \mathrm{~mm})$ to make porous clay bricks, which were then sun-dried for 48-72 hrs. Finally, the bricks were fired at $900{ }^{\circ} \mathrm{C}$ for $2 \mathrm{~h}$ at a rate of $10^{\circ} \mathrm{C} / \mathrm{min}$. Table 1 presents the main physical and hydrological properties of the clay bricks [29]. The details on the permeable clay bricks' manufacturing can be seen in Al Harbi et al. [29].

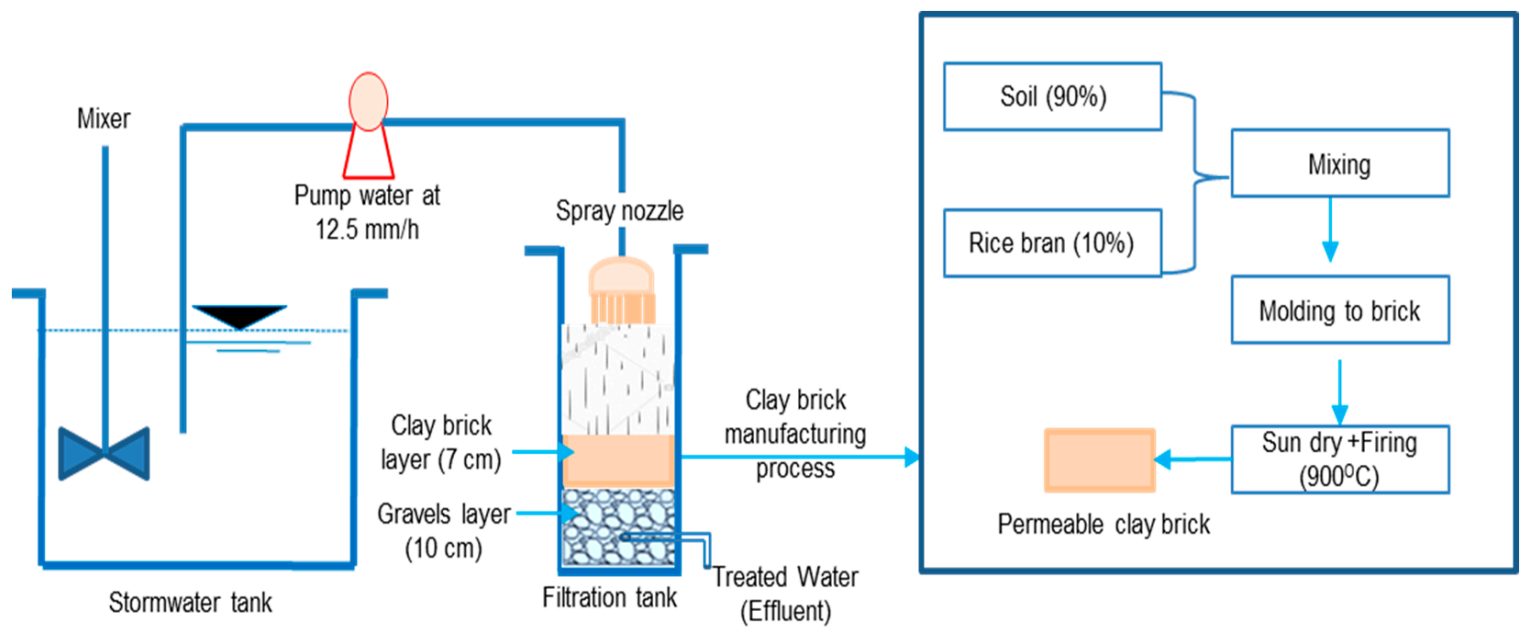

Figure 1. Schematics of laboratory-scale stormwater infiltration experiment.

Table 1. Physical and hydrological properties of porous clay bricks.

\begin{tabular}{cc}
\hline Parameters & Values \\
\hline Compressive strength $(\mathrm{MPa})$ & 18.8 \\
Flexural strength $(\mathrm{MPa})$ & 0.75 \\
Permeability coefficient $(\mathrm{mm} / \mathrm{s})$ & $2.38 \times 10^{-3}$ \\
Porosity $(\%)$ & 29.2 \\
Water adsorption $(\%)$ & 22.3 \\
Bulk density $\left(\mathrm{kg} / \mathrm{m}^{3}\right)$ & 1.61 \\
\hline
\end{tabular}

\subsection{Stormwater Sampling}

The samples were collected from two different SW storage ponds in Buraidah City, AlQassim, Saudi Arabia. The first sample was collected from the pond located at $26.3489^{\circ} \mathrm{N}$ and $43.7668^{\circ} \mathrm{E}$ in Qassim University (QU), Buraidah Campus. The second sample was collected from a pond located near the center of Buraidah city at $26.3489^{\circ} \mathrm{N}$ and $43.7668^{\circ} \mathrm{E}$. Both samples were collected immediately after a rainfall event (with $24.2 \mathrm{~mm}$ rainfall) on 16 February 2019. Each sample was collected in pre-washed high-density polyethylene (HDPE) bottles and transported to the Environmental Engineering Laboratory of the College of Engineering at QU for succeeding analysis. All the samples were stored in a refrigerator at $4{ }^{\circ} \mathrm{C}$ without any pretreatment. The samples were analyzed for $\mathrm{pH}, \mathrm{DO}, \mathrm{BOD}_{5}$, and COD within $48 \mathrm{~h}$ of sampling. For other water quality tests, the samples were preserved in acid-washed glass bottles and sent to the General Directorate of Water in Qassim Region, 
Saudi Arabia. Around 200 L SW sample from each site was collected to conduct rainfall infiltration tests within $48 \mathrm{~h}$ of sample collection.

\subsection{Experimental Setup}

Figure 1 displays the experimental setup established in the present research. An acryl glass box was used for the laboratory scale runoff infiltration experiments. To assess the pollutant removal capability of the brick's layer, the pavement system for the laboratory experiments was constructed by a $7 \mathrm{~cm}$ brick layer on the top with a $10 \mathrm{~cm}$ support layer of coarse gravel (size 5.0-20.0 mm). The top layer of porous brick was made of a mixture of rice bran and clay soil as stated in the above section. An SW storage tank was installed with a peristaltic pump to simulate and control the design rainfall. The SW in the influent tank was stirred continuously by a paddle stirrer to ensure homogeneous mixing and to avoid any settlement of particulate matters. A drainage pipe was set at the bottom of the box to drain the infiltrated SW to the effluent tank. A spray nozzle was installed at the end of the influent pipe and set at the top of the filtration tank to simulate the real rainfall.

\subsection{Runoff Infiltration Experiments}

The runoff infiltration experiments were initiated by pumping the SW to the infiltration tank at the designed rainfall intensity. Separate experiments were conducted for the two SW samples. As the present study aimed to assess the pollution removal performance of the porous clay brick, the SWs were named as high-strength polluted stormwater (HPSW) and low-strength polluted stormwater (LPSW), based on the level of contamination. The experiments were conducted at a rainfall intensity of $12.5 \mathrm{~mm} / \mathrm{h}$. The rainfall intensity was selected based on a previous study that used a 10-year return period and $120 \mathrm{~min}$ rainfall duration for estimating the rainfall intensity in Al Qassim, Saudi Arabia [30,31]. Effluent samples were collected from the outlet tank at designated intervals (representing rainfall duration) of 10, 30, 45, 60, 90, and $120 \mathrm{~min}$. The effluent volume was also recorded at each sampling interval to measure the rate of infiltration. All tests were conducted in triplicate at room temperature ranging between 20 and $25^{\circ} \mathrm{C}$. The removal efficiencies of physical and chemical pollutants, including TSS, turbidity, organics (BOD, COD, and TOC), nutrients (TN, $\mathrm{NH}_{3}-\mathrm{N}, \mathrm{NO}_{3}-\mathrm{N}, \mathrm{NO}_{2}-\mathrm{N}$, and TP), and heavy metals ( $\mathrm{Fe}, \mathrm{Mn}, \mathrm{B}, \mathrm{Ba}, \mathrm{Cd}, \mathrm{Cr}$, $\mathrm{Cu}, \mathrm{Ni}, \mathrm{Pb}, \mathrm{Se}$, and $\mathrm{Zn}$ ), were investigated. Table 2 outlines the standard methods and the equipment used to conduct the laboratory analysis for all the water quality parameters.

Table 2. Laboratory methods used in water quality analysis of the samples.

\begin{tabular}{|c|c|c|}
\hline Parameter & Method & Manufacturer \\
\hline $\mathrm{pH}, \mathrm{DO}$, and $\mathrm{EC}$ & $\mathrm{HACH}$ portable $\mathrm{pH}, \mathrm{EC}$, and $\mathrm{DO}$ meter & HQ11D53000000, HACH, Loveland, CO, USA \\
\hline Turbidity & Hach $2100 Q$ turbidity meter & 2100Q, HACH, Loveland, CO, USA \\
\hline TDS & Hach HQ411d TDS meter & $\mathrm{HACH}$, Loveland, $\mathrm{CO}$, USA \\
\hline Alkalinity & Titration Method 2320 & - \\
\hline BOD & 5-d BOD Method 5210: 2000 & - \\
\hline TOC & TOC analyzer & Shimadzu, Japan \\
\hline COD & $\begin{array}{l}\text { Closed Reflux, Colorimetric Method } 5220 \text { D: } \\
2000\end{array}$ & - \\
\hline Total Phosphorous (TP) & 4500-P E. ascorbic acid method & - \\
\hline Total nitrogen $(\mathrm{TN})$ & Kjeldahl method (4500-Norg B: 2000) & - \\
\hline Nitrate $\left(\mathrm{NO}_{3}-\mathrm{N}\right)$ & Nitrate electrode method (4500- $\mathrm{NO}_{3}$ D: 2000$)$ & - \\
\hline Nitrite $\left(\mathrm{NO}_{2}-\mathrm{N}\right)$ & Colorimetric method (4500- $\left.\mathrm{NO}_{2} \mathrm{~B}: 2000\right)$ & - \\
\hline Ammonia nitrogen $\left(\mathrm{NH}_{3}-\mathrm{N}\right)$ & Titrimetric method (4500- $\left.\mathrm{NH}_{3} \mathrm{C}: 2000\right)$ & _ \\
\hline $\mathrm{Fe}, \mathrm{Mn}, \mathrm{B}, \mathrm{Ba}, \mathrm{Pb}, \mathrm{Zn}, \mathrm{Ni}, \mathrm{Cu}, \mathrm{Cd}, \mathrm{Se}, \mathrm{Ba}$ and $\mathrm{Cr}$ & Inductive coupled Plasma Mass Spectrometer & PerkinElmer, NexION ${ }^{\mathrm{TM}} 300$ ICP-MS \\
\hline
\end{tabular}

All analyses were performed according to the methods defined by American Public Health Association [32].

\section{Results}

\subsection{Infiltration Rate of the Permeable Clay Brick Layer}

Figure 2 presents the observed infiltration rates for the permeable clay brick. The outflow water was measured at $5 \mathrm{~min}$ intervals for the first $30 \mathrm{~min}$ and $15 \mathrm{~min}$ intervals for the remaining $90 \mathrm{~min}$. The infiltration rate increased sharply for a short period until $10 \mathrm{~min}$; 
later, it became steady and approached the saturated hydraulic conductivity. No outflow was observed until $5 \mathrm{~min}$ of rainfall. After $10 \mathrm{~min}$, the average steady-state infiltration rate of $9.8 \pm 0.52 \mathrm{~mm} / \mathrm{h}$ was measured for HPSW and $10.0 \pm 0.46 \mathrm{~mm} / \mathrm{h}$ for LPSW. These results are consistent with a previous study that reported $10 \mathrm{~min}$ for reaching a steady-state condition for the ceramic permeable brick layer [25].

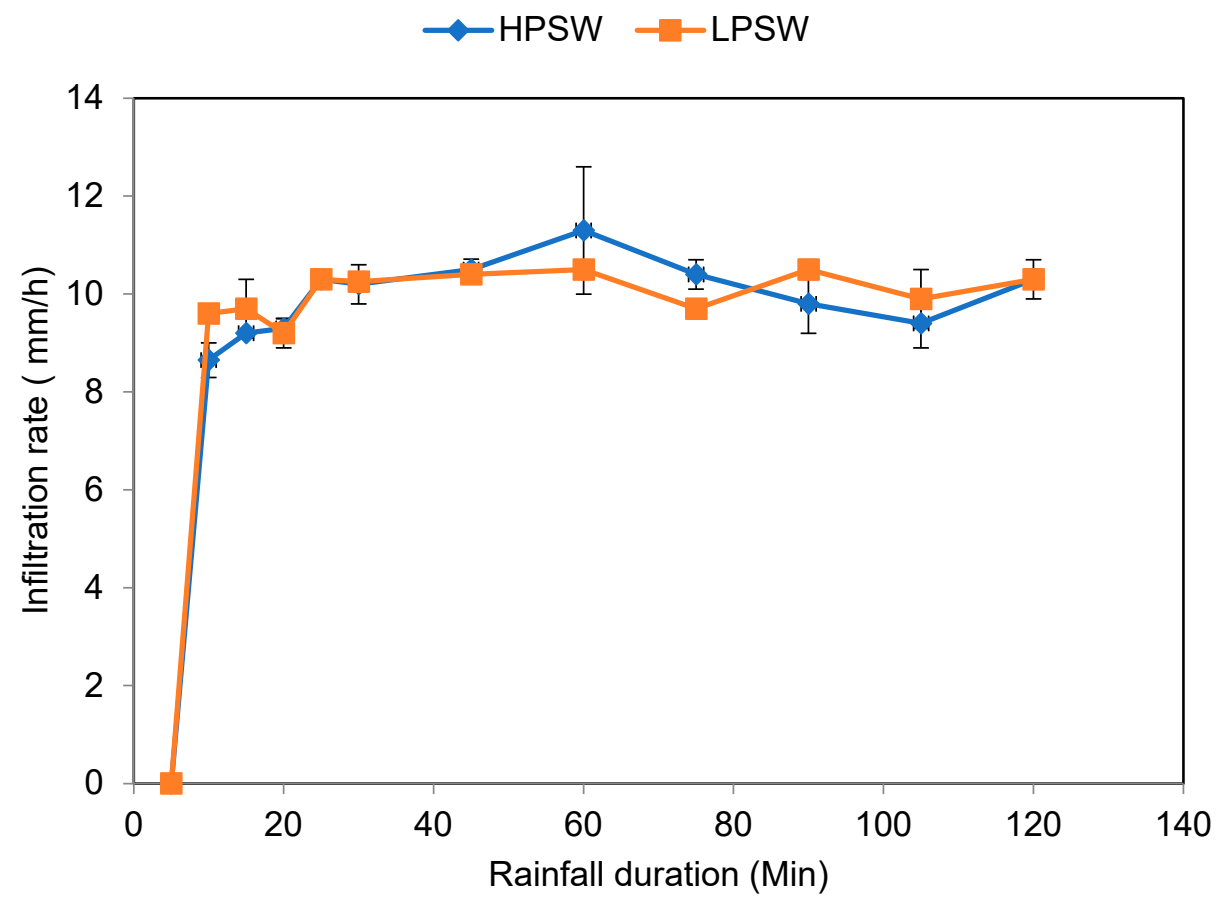

Figure 2. Infiltration rate of the permeable clay bricks during the rainfall experiments of two stormwater.

\subsection{Stormwater Quality}

Table 3 shows the characteristics of HPSW and LPSW used in the infiltration experiments. The $\mathrm{pH}$ values were in a desirable range for any reuse application. Turbidity was higher than the standard limit, measured respectively 39.1 and 25.9 NTU for HPSW and LPSW. Total suspended solids (TSS) concentrations were measured $374 \mathrm{mg} / \mathrm{L}$ for LPSW, whereas it was more than two-fold higher $(810 \mathrm{mg} / \mathrm{L})$ for HPSW. Total dissolved solids (TDS) and electrical conductivity (EC) of both SWs were within the standard limit for reuse application set by Saudi Arabia and World Health Organization [33-36]. BOD 5 $(61.33 \mathrm{mg} / \mathrm{L})$ and COD (95.68 mg/L) concentrations in HPSW were about two-fold higher than that of LPSW and both exceeded the standard limit for reuse application. TN level $(13.84 \mathrm{mg} / \mathrm{L})$ was also measured much higher in HPSW $(13.84 \mathrm{mg} / \mathrm{L})$ than in the LPSW $(1.96 \mathrm{mg} / \mathrm{L})$. TP concentrations were low and measured 2.87 and $1.60 \mathrm{mg} / \mathrm{L}$, respectively, for HPSW and LPSW. Table 3 shows that all the measured heavy metals (except Se and Pb in HPSW) exceeded the standard limits, and their concentrations were higher in the HPSW than in the LPSW. The SW characteristics analyses in this study revealed that the SW will cause environmental problems and deteriorate the water quality of the receiving bodies if discharged without any pre-treatment.

\subsection{Stormwater Treatment Performance of the Clay Bricks}

\subsubsection{Variation of $\mathrm{pH}, \mathrm{DO}$, Alkalinity, and EC}

The variation of $\mathrm{pH}, \mathrm{DO}$, alkalinity, and EC of two SW samples at different rainfall durations is presented in Figure 3. No significant change of pH was observed for HPSW and LPSW that ranged from 7.0 to 8.0. Dissolved oxygen (DO) also remained almost unchanged and was kept between 5.6-7.0 mg/L for the HPSW and LPSW. Alkalinity and 
EC also almost remained unchanged throughout the infiltration time. The results indicated that stormwater infiltration through clay bricks did not affect the physical water quality and did not meet the standard guideline for reuse applications [33-36].

Table 3. Characteristics of two SWs strengths used in the infiltration experiments.

\begin{tabular}{|c|c|c|c|c|c|}
\hline \multirow{2}{*}{ Parameter } & \multirow{2}{*}{ Unit } & \multicolumn{2}{|c|}{ HPSW } & \multicolumn{2}{|c|}{ LPSW } \\
\hline & & MEAN & SD & MEAN & SD \\
\hline $\mathrm{pH}$ & - & 8.24 & 0.30 & 7.79 & 0.12 \\
\hline TSS & $\mathrm{mg} / \mathrm{L}$ & 810.00 & 61.49 & 374.33 & 32.96 \\
\hline Alkalinity & $\mathrm{mg} / \mathrm{L}$ & 98.33 & 4.73 & 38.33 & 14.57 \\
\hline $\mathrm{EC}$ & $\mu S / \mathrm{cm}$ & 482.67 & 47.88 & 641.33 & 39.80 \\
\hline DO & $\mathrm{mg} / \mathrm{L}$ & 7.43 & 0.81 & 6.65 & 1.14 \\
\hline Turbidity & NTU & 39.10 & 10.69 & 25.93 & 12.10 \\
\hline TDS & $\mathrm{mg} / \mathrm{L}$ & 347.00 & 65.64 & 446.00 & 19.92 \\
\hline $\mathrm{BOD}_{5}$ & $\mathrm{mg} / \mathrm{L}$ & 61.33 & 6.43 & 27.08 & 6.51 \\
\hline COD & $\mathrm{mg} / \mathrm{L}$ & 95.68 & 10.03 & 42.24 & 10.15 \\
\hline TOC & $\mathrm{mg} / \mathrm{L}$ & 11.72 & 1.54 & 4.59 & 0.97 \\
\hline $\mathrm{TN}$ & $\mathrm{mg} / \mathrm{L}$ & 13.84 & 1.70 & 1.96 & 0.15 \\
\hline $\mathrm{NH}_{3}-\mathrm{N}$ & $\mathrm{mg} / \mathrm{L}$ & 7.87 & 1.05 & 0.76 & 0.14 \\
\hline $\mathrm{NO}_{2}-\mathrm{N}$ & $\mathrm{mg} / \mathrm{L}$ & 0.07 & 0.02 & 0.26 & 0.06 \\
\hline $\mathrm{NO}_{3}-\mathrm{N}$ & $\mathrm{mg} / \mathrm{L}$ & 4.47 & 0.38 & 0.48 & 0.17 \\
\hline $\mathrm{TP}$ & $\mathrm{mg} / \mathrm{L}$ & 2.87 & 0.50 & 1.60 & 0.10 \\
\hline $\mathrm{Fe}$ & $\mu \mathrm{g} / \mathrm{L}$ & 210.00 & 20.00 & 26.67 & 20.82 \\
\hline Mn & $\mu \mathrm{g} / \mathrm{L}$ & 66.67 & 11.55 & 49.67 & 10.50 \\
\hline B & $\mu \mathrm{g} / \mathrm{L}$ & 175.73 & 52.10 & 63.50 & 24.20 \\
\hline $\mathrm{Ba}$ & $\mu \mathrm{g} / \mathrm{L}$ & 46.23 & 9.54 & 26.80 & 6.58 \\
\hline $\mathrm{Cd}$ & $\mu \mathrm{g} / \mathrm{L}$ & ND & ND & ND & ND \\
\hline $\mathrm{Cr}$ & $\mu \mathrm{g} / \mathrm{L}$ & 20.99 & 6.37 & 20.02 & 4.89 \\
\hline $\mathrm{Cu}$ & $\mu \mathrm{g} / \mathrm{L}$ & 98.75 & 4.12 & 84.90 & 8.40 \\
\hline $\mathrm{Ni}$ & $\mu \mathrm{g} / \mathrm{L}$ & ND & ND & ND & ND \\
\hline $\mathrm{Pb}$ & $\mu \mathrm{g} / \mathrm{L}$ & 38.51 & 17.15 & 9.65 & 0.57 \\
\hline Se & $\mu g / L$ & 32.31 & 14.27 & ND & ND \\
\hline $\mathrm{Zn}$ & $\mu g / L$ & 372.30 & 75.32 & 366.83 & 107.92 \\
\hline
\end{tabular}

ND: not detected.

\subsubsection{TSS, Turbidity and TDS Removal}

The TSS, turbidity, and TDS concentrations in the outflow at different sampling times are shown in Figure 4. TSS concentration in HPSW and LPSW decreased dramatically after filtration and then remained unchanged over the rainfall duration. Influent TSS concentration in HPSW was 810 and $374 \mathrm{mg} / \mathrm{L}$ in LPSW, which was reduced to 8.2 and $6.1 \mathrm{mg} / \mathrm{L}$, respectively. The corresponding average TSS removal efficiencies were $98.9 \%$ and $98.3 \%$. Such high removal agrees with the previous study that reported high effectiveness of ceramic brick layer for TSS removal from the SW $[19,25]$. Figure 4 shows that turbidity was also efficiently removed from HPSW and LPSW, while TDS concentrations remained unchanged throughout the rainfall duration. Regardless of the influent turbidity, the effluent turbidities of the HPSW and LPSW were found to be less than 1.0 NTU, which represents more than $99 \%$ removal. The results demonstrate that clay brick efficiently removes suspended and colloidal particles, while being ineffective in TDS removal from stormwater. The removal of suspended and colloidal particles primarily occurred from the interference and adsorption of internal micro-pores in the brick surface layer [25]. The infiltration rate in the clay bricks remained consistent throughout the rainfall duration (refer to Figure 2), indicating no clogging of brick surfaces during $120 \mathrm{~min}$ infiltration. Nevertheless, the surface of the brick might be clogged in the case of longer rainfall duration, which can be investigated in some future studies. The overall results demonstrated that clay bricks have excellent retention capability of TSS as well as turbidity and have the potential to be used in the permeable pavement system as the surface layer. 


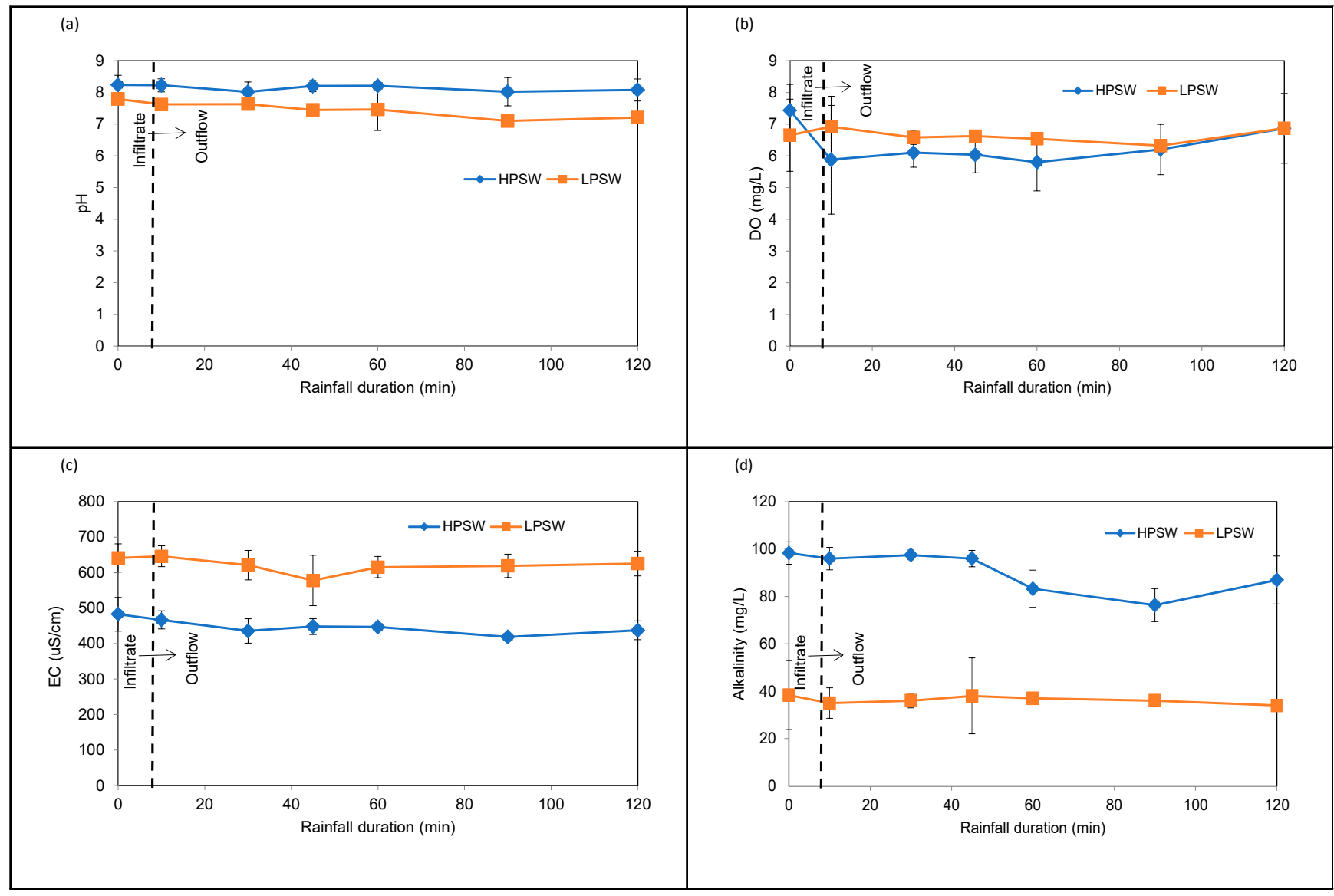

Figure 3. Variations of (a) $\mathrm{pH},(\mathbf{b}) \mathrm{DO}$, (c) alkalinity, and (d) EC before and after infiltration through permeable bricks.

\subsubsection{Removal of Organics}

Figure 5 presents the variations of $\mathrm{BOD}_{5}, \mathrm{COD}$, and TOC before and after infiltration through permeable clay bricks. Significant removals of organics were observed during the infiltration of HPSW and LPSW through the clay brick layer. The influent $\mathrm{BOD}_{5}$ of HPSW and LPSW were 61.3 and $27.4 \mathrm{mg} / \mathrm{L}$, which were reduced to 14.1 and $8.7 \mathrm{mg} / \mathrm{L}$, respectively. Similarly, COD concentrations reduced from 95.6 to $29.6 \mathrm{mg} / \mathrm{L}$ for HPSW and 42.2 to $11.1 \mathrm{mg} / \mathrm{L}$ for LPSW. It was observed from Figure 5 that removals of COD and $\mathrm{BOD}_{5}$ were consistent throughout the rainfall duration. The average removal efficiency of $\mathrm{BOD}_{5}$ was $77.0 \%$ and $67.8 \%$ during the $120 \mathrm{~min}$ rainfall, respectively, for HPSW and LPSW; the corresponding COD removal efficiencies were $68.9 \%$ and $73.5 \%$. Throughout the rainfall duration, effluent $\mathrm{BOD}_{5}$ and $\mathrm{COD}$ values remained less than 20 and $40 \mathrm{mg} / \mathrm{L}$ irrespective of the influent concentrations, indicating organics removal potential of clay bricks for a wide range of polluted SW.

TOC reduction was 20.8\% (11.7 initial concentration) for HPSW and $41.5 \%$ (4.6 mg/L initial concentration) for LPSW. Typically, organics removal from wastewater is carried out by biological oxidation and physico-chemical adsorption processes. Among these processes, physical interception of the surface layers structure and adsorption play important roles in BOD and COD removal, especially in short duration $[19,24]$. The TSS levels in the studied HPSW and LPSW were higher and seemed to contain a high particulate organic content. Therefore, the particulate portion of organics was removed by the physical straining of the micro-porous clay brick layer, whereas the dissolved organics portion was removed through adsorption onto the porous layers of the natural clay bricks. A previous study by Ogunmodede et al. [37] also reported that natural clay possesses some sorption capability for organics in wastewater. 


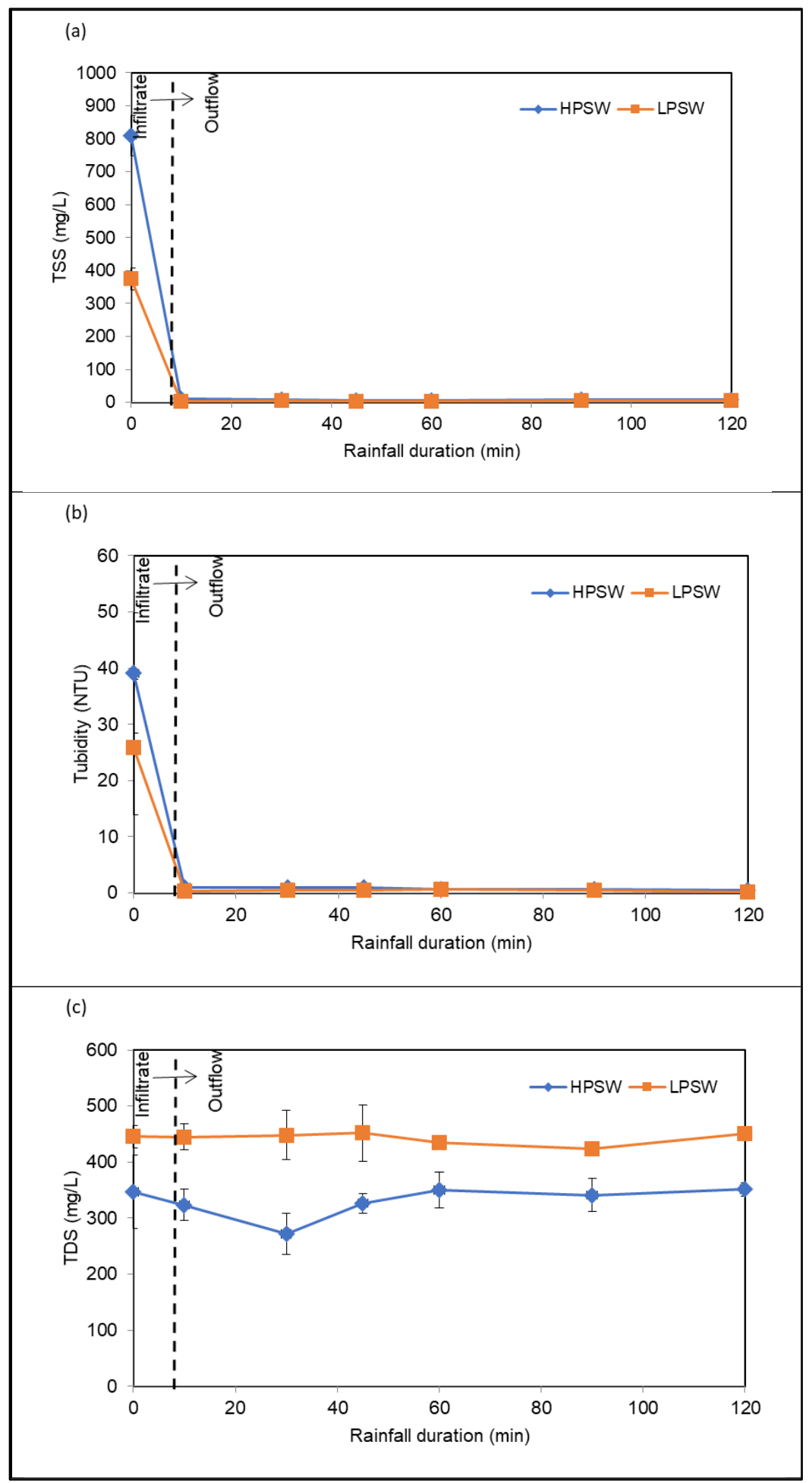

Figure 4. Variations of (a) TSS, (b) turbidity, and (c) TDS before and after infiltration through permeable clay bricks. 


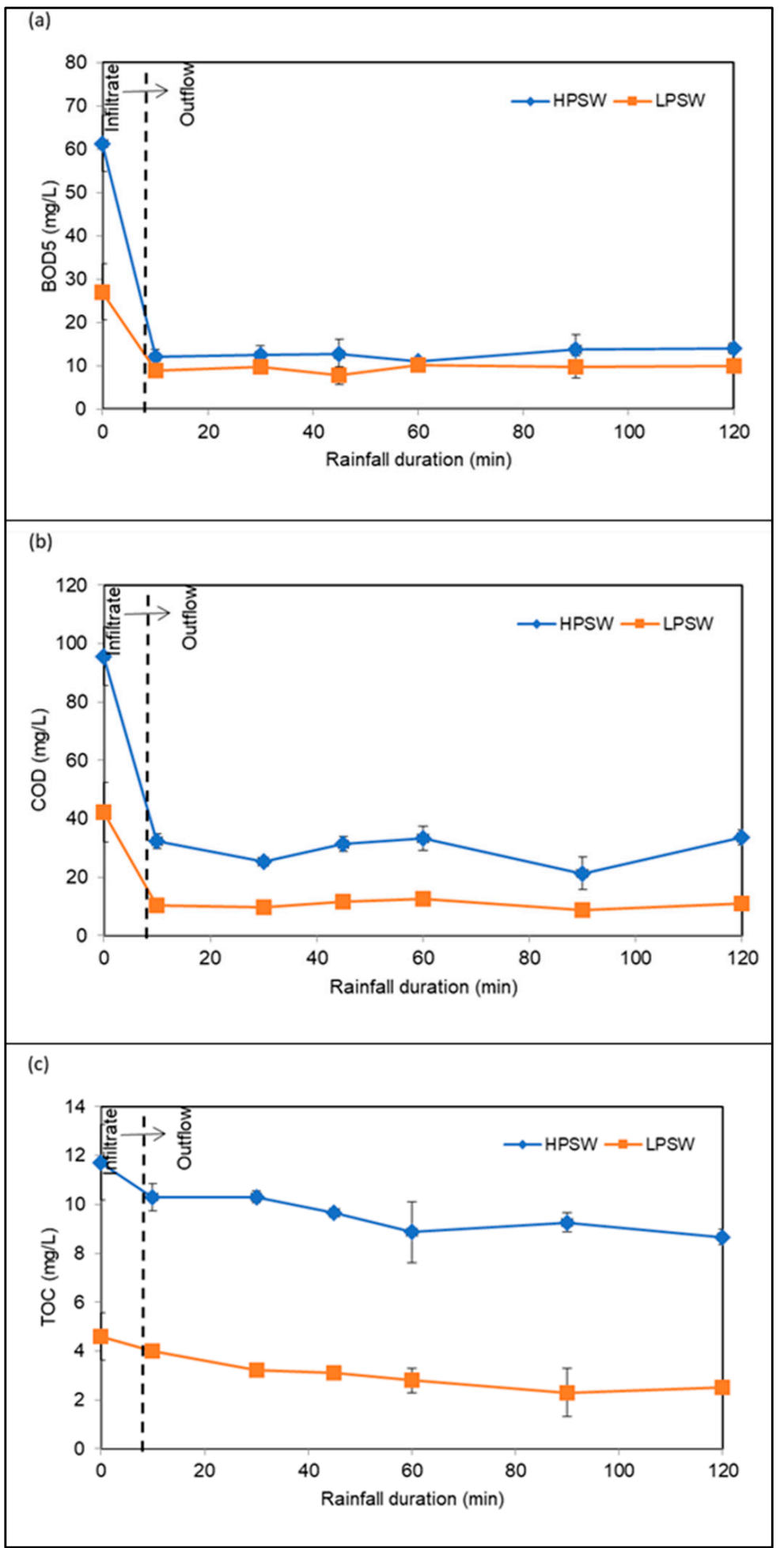

Figure 5. Variations of (a) BOD5, (b) COD, and (c) TOC before and after infiltration through permeable clay bricks.

\subsubsection{Removal of Nutrients}

Removal of TN and TP during infiltration is presented in Figure 6. Analysis of the nitrogen compounds showed that HPSW and LPSW were mainly composed of $\mathrm{NH}_{3}-\mathrm{N}$ (38.0-56.8\%) and $\mathrm{NO}_{3}-\mathrm{N}(25.0-32.2 \%)$ (calculated from Table 3), which is consistent with the previous study [18]. The TN concentrations in HPSW and LPSW were reduced to 9.9 and $1.19 \mathrm{mg} / \mathrm{L}$ from the influent concentrations of 13.8 and $1.96 \mathrm{mg} / \mathrm{L}$. The corresponding 
average removals were 30.5\% for HPSW and 39.1\% for LPSW after 120 min of rainfall, indicating a moderate TN removal by the clay brick layer. Mostly, TN removal from water relies on the adsorption matrix and microbial nitrification and denitrification process [38]. In this study, TN removal via the clay brick layer primarily occurred from the adsorption of $\mathrm{NH}_{3}-\mathrm{N}$ and $\mathrm{NO}_{3}-\mathrm{N}$ onto the clay bricks. The nitrification and denitrification processes were absent due to the limited microbial effect during the short infiltration period $(2 \mathrm{~h})$. Figure 7 presents the variations of $\mathrm{NH}_{3}-\mathrm{N}, \mathrm{NO}_{3}-\mathrm{N}$, and $\mathrm{NO}_{2}-\mathrm{N}$ during the infiltration through the brick layer. The results showed that a significant amount of $\mathrm{NH}_{3}-\mathrm{N}(22.7 \%$ and $69.2 \%)$ and $\mathrm{NO}_{3}-\mathrm{N}(13.2 \%$ and $35.2 \%)$ were reduced from HPSW and LPSW. The removal of $\mathrm{NO}_{3}-\mathrm{N}$ by the clay bricks can be attributed to possible adsorption onto the clay bricks. Moreover, the clay bricks contain a high amount of monovalent cation $\mathrm{Na}+$ and $\mathrm{K}+$ ions and can be readily available for cations exchange reaction with $\mathrm{NH}_{3}-\mathrm{N}$, which may lead to $\mathrm{NH}_{3}-\mathrm{N}$ removal [39]. TN removal efficiency of the clay brick layer showing a similar pattern for HPSW and LPSW indicates the effectiveness of the designed permeable pavement for a diverse range of polluted stormwater.

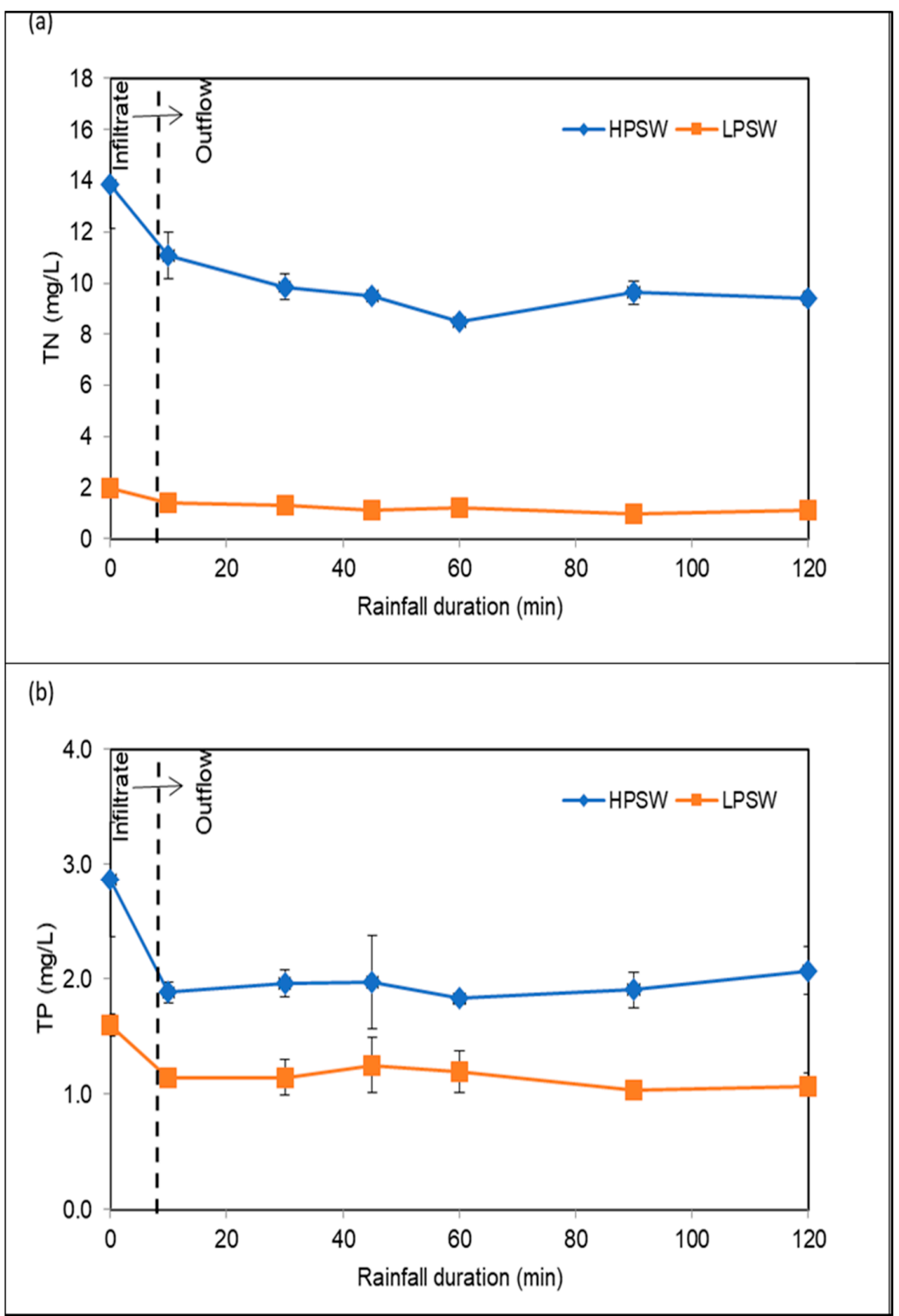

Figure 6. Variations of (a) TN and (b) TP before and after infiltration through permeable clay bricks. 


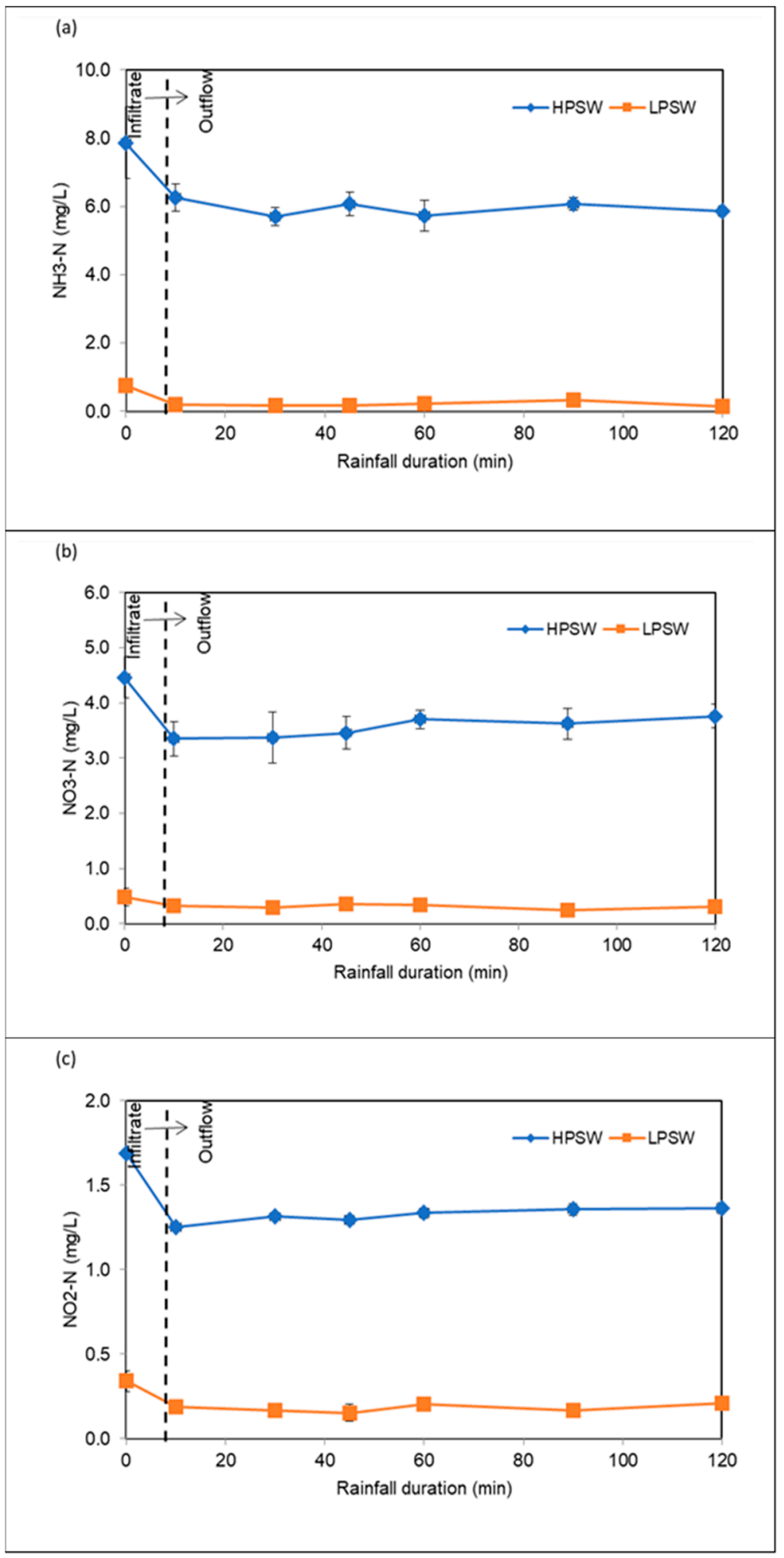

Figure 7. Variations of (a) $\mathrm{NH}_{3}-\mathrm{N}$, (b) $\mathrm{NO}_{3}-\mathrm{N}$, and (c) $\mathrm{NO}_{2}-\mathrm{N}$ before and after infiltration through permeable clay bricks.

Figure 6 presents the TP variations at different rainfall durations. The average TP removal was achieved at 34.7\% for HPSW and 31.3\% for LPSW. The influent TP concentrations of 2.8 and $1.6 \mathrm{mg} / \mathrm{L}$ were reduced to 1.8 and $1.1 \mathrm{mg} / \mathrm{L}$, respectively, at the outlet for HPSW and LPSW. The phosphorus removal by clay bricks can be attributed to the 
chemical adsorption of phosphate anions onto the clay-based filter or physical interception of precipitated phosphorous in the pore structure of the clay bricks [25].

\subsubsection{Removal of Heavy Metals}

Figure 8 illustrates the variation of heavy metal concentrations in the clay bricks experiments. It was observed that the performance of the clay bricks was moderate to high for heavy metals removal from stormwater. The removal showed a similar pattern for both HPSW and LPSW achieving, respectively, $88.5 \%$ and $94.3 \%$ removal for $\mathrm{Fe}, 70.2 \%$ and $76.5 \%$ for $\mathrm{Mn}, 23.2 \%$ and $24.1 \%$ for $\mathrm{B}, 49.5 \%$ and $38.3 \%$ for $\mathrm{Ba}, 33.2 \%$ and $6.7 \%$ for $\mathrm{Cr}, 54.5 \%$ and $68.9 \%$ for $\mathrm{Cu}, 94.5 \%$ and $94.2 \%$ for $\mathrm{Pb}$, and $48.7 \%$ and $69.7 \%$ for $\mathrm{Zn}$ (Figure 9 ). Removal of all heavy metals remained consistent over the rainfall duration. $\mathrm{pH}$ is the most critical parameter for the oxidation and precipitation of heavy metals during the infiltration process. In this study, both HPSW and LPSW had average $\mathrm{pH}$ values of 8.24 and 7.79, which slightly changed to 8.0 and 7.33 after infiltration through the clay bricks. Most of the metals can form precipitates in this range of $\mathrm{pH}$ [40] and can be removed by the micro-porous clay bricks. Some of the heavy metals including $\mathrm{Cu}$ and $\mathrm{Zn}$ can also be removed through the nonspecific electrostatic adsorption process on the clay-based bricks [41]. Heavy metals removal by the clay bricks is comparable with other LID technologies (Table 4), which indicates the suitability of the clay bricks for use as an alternative option to remove pollutants from SWs.

Table 4. SWs quality of two processes and standard limit for recycling and drinking water.

\begin{tabular}{|c|c|c|c|c|c|c|c|c|c|c|c|c|}
\hline \multirow[b]{2}{*}{ Parameters } & \multicolumn{4}{|c|}{ Contaminants Removal by Clay Bricks (This Study) } & \multicolumn{4}{|c|}{ Contaminants Removal \% by Other LID Technologies } & \multicolumn{4}{|c|}{$\begin{array}{l}\text { National and International Standard for Drinking Water and } \\
\text { Wastewater Reuse }\end{array}$} \\
\hline & $\begin{array}{c}\text { HPSW } \\
\text { Effluent }\end{array}$ & $\begin{array}{l}\text { LPSW } \\
\text { Effluent }\end{array}$ & $\begin{array}{l}\text { Removal } \\
\text { (\%) HPSW }\end{array}$ & $\begin{array}{l}\text { Removal } \\
\text { (\%) LPSW }\end{array}$ & $\begin{array}{c}\text { Bio- } \\
\text { Retention } \\
\text { Systems [42] }\end{array}$ & $\begin{array}{c}\text { Permeable } \\
\text { Pavements } \\
\text { [42] }\end{array}$ & $\begin{array}{c}\text { Grass } \\
\text { Swales [42] }\end{array}$ & $\begin{array}{c}\text { Sand Filter } \\
{[43]}\end{array}$ & $\begin{array}{l}\text { KSA Reuse } \\
\text { Standard }\end{array}$ & $\begin{array}{l}\text { WHO Reuse } \\
\text { Standard }\end{array}$ & $\begin{array}{c}\text { KSA } \\
\text { Drinking } \\
\text { Water } \\
\text { Standard }\end{array}$ & $\begin{array}{c}\text { WHO } \\
\text { Drinking } \\
\text { Water } \\
\text { Standard }\end{array}$ \\
\hline $\mathrm{pH}$ & $8.0 \pm 0.34$ & $7.33 \pm 0.31$ & - & - & - & - & - & - & $6-8.4$ & $6.0-9.0$ & $6.5-8.5$ & $6.5-8$ \\
\hline $\mathrm{DO}(\mathrm{mg} / \mathrm{L})$ & $6.5 \pm 0.88$ & $6.9 \pm 0.52$ & - & - & - & - & - & - & - & - & - & - \\
\hline $\begin{array}{c}\text { Alkalinity } \\
(\mathrm{mg} / \mathrm{L})\end{array}$ & $87.8 \pm 6.5$ & $33.7 \pm 6.5$ & - & - & - & - & - & - & - & - & - & - \\
\hline $\mathrm{EC}(\mathrm{us} / \mathrm{cm})$ & $441 \pm 31$ & $585 \pm 44$ & 8.6 & 8.7 & - & - & - & -0.92 & - & - & - & - \\
\hline $\begin{array}{l}\text { Turbidity } \\
\text { (NTU) }\end{array}$ & $0.62 \pm 0.28$ & $0.24 \pm 0.12$ & 98.4 & 99 & & & & & 5 & - & $<5$ & - \\
\hline $\mathrm{TSS}(\mathrm{mg} / \mathrm{L})$ & $8.2 \pm 1.6$ & $6.1 \pm 2.2$ & 98.9 & 98.3 & $47-99$ & $58-94$ & $46-97$ & $32-93.5$ & & & & \\
\hline TDS $(\mathrm{mg} / \mathrm{L})$ & $320 \pm 28$ & $422 \pm 18$ & 7.7 & 5.2 & - & - & - & - & 2500 & - & 700 & - \\
\hline $\begin{array}{l}\mathrm{BOD}_{5} \\
(\mathrm{mg} / \mathrm{L})\end{array}$ & $14.1 \pm 2.1$ & $8.7 \pm 2.7$ & 77 & 67.8 & - & - & - & - & 10 & 10 & & - \\
\hline $\begin{array}{c}\mathrm{COD} \\
(\mathrm{mg} / \mathrm{L})\end{array}$ & $29.6 \pm 8.3$ & $11.1 \pm 2.3$ & 68.9 & 73.5 & - & - & - & - & 50 & - & - & - \\
\hline $\mathrm{TOC}(\mathrm{mg} / \mathrm{L})$ & $9.3 \pm 1.2$ & $2.6 \pm 0.9$ & 20.8 & 41.5 & - & - & $23-64$ & - & - & - & - & - \\
\hline $\mathrm{TN}(\mathrm{mg} / \mathrm{L})$ & $9.6 \pm 0.79$ & $1.19 \pm 0.19$ & 30.5 & 39.1 & $32-99$ & $>75$ & $14-61$ & -107.6 & - & - & - & - \\
\hline $\begin{array}{l}\mathrm{NH}_{3-\mathrm{N}} \\
(\mathrm{mg} / \mathrm{L})\end{array}$ & $6.1 \pm 0.4$ & $0.24 \pm 0.11$ & 22.7 & 69.2 & & & & & 5 & - & - & - \\
\hline $\begin{array}{l}\mathrm{NO}_{2}-\mathrm{N} \\
(\mathrm{mg} / \mathrm{L})\end{array}$ & $0.02 \pm 0.02$ & $0.14 \pm 0.01$ & 71.8 & 44.8 & - & - & - & - & - & - & - & - \\
\hline $\begin{array}{l}\mathrm{NO}_{3}-\mathrm{N} \\
(\mathrm{mg} / \mathrm{L})\end{array}$ & $3.9 \pm 0.11$ & $0.31 \pm 0.04$ & 13.2 & 35.2 & $1-83$ & - & - & - & 10 & - & - & - \\
\hline $\mathrm{TP}(\mathrm{mg} / \mathrm{L})$ & $1.87 \pm 0.1$ & $1.10 \pm 0.1$ & 34.7 & 31.3 & - & - & - & - & - & - & - & - \\
\hline $\mathrm{Fe}(\mu \mathrm{g} / \mathrm{L})$ & $24 \pm 11$ & $1.5 \pm 2.5$ & 88.5 & 94.3 & & & & & 5000 & 5000 & 300 & 300 \\
\hline $\mathrm{Mn}(\mu \mathrm{g} / \mathrm{L})$ & $20 \pm 5$ & $11 \pm 4$ & 70.2 & 76.5 & & & & & 200 & 200 & 100 & 100 \\
\hline $\mathrm{B}(\mu \mathrm{g} / \mathrm{L})$ & $135 \pm 24$ & $48.1 \pm 8.5$ & 23.2 & 24.1 & - & - & - & - & - & - & - & 24,000 \\
\hline $\mathrm{Ba}(\mu \mathrm{g} / \mathrm{L})$ & $23.3 \pm 5.3$ & $16.5 \pm 4.7$ & 49.5 & 38.3 & - & - & - & - & - & - & - & 1300 \\
\hline $\mathrm{Cr}(\mu \mathrm{g} / \mathrm{L})$ & $14.0 \pm 5.1$ & $111 \pm 12.1$ & 33.2 & 6.7 & - & - & - & - & 100 & 100 & 50 & 50 \\
\hline $\mathrm{Cu}(\mu \mathrm{g} / \mathrm{L})$ & $44.9 \pm 34$ & $26.3 \pm 5.6$ & 54.5 & 68.9 & $43-97$ & 20-99 & $14-67$ & -83 & 300 & 200 & 1000 & 2000 \\
\hline $\mathrm{Zn}(\mu \mathrm{g} / \mathrm{L})$ & $191.8 \pm 9.9$ & $26.3 \pm 5.7$ & 48.7 & 69.7 & $62-97$ & 73-99 & $47-81$ & $0-93$ & 4000 & 2000 & 5000 & 3000 \\
\hline $\mathrm{Pb}(\mu \mathrm{g} / \mathrm{L})$ & $2.1 \pm 1.2$ & $0.55 \pm 0.61$ & 94.5 & 94.2 & $31-98$ & $75-99$ & $18-94$ & -122 & 100 & 5000 & 50 & 10 \\
\hline $\mathrm{Se}(\mu \mathrm{g} / \mathrm{L})$ & $1.97 \pm 0.77$ & ND & 93.9 & - & - & - & - & - & 20 & 20 & 10 & 40 \\
\hline $\mathrm{Cd}(\mu \mathrm{g} / \mathrm{L})$ & ND & ND & - & - & - & - & $12-98$ & - & 10 & 100 & 5 & 3 \\
\hline $\mathrm{Ni}(\mu \mathrm{g} / \mathrm{L})$ & ND & ND & - & - & - & - & - & - & 200 & 200 & - & 70 \\
\hline
\end{tabular}




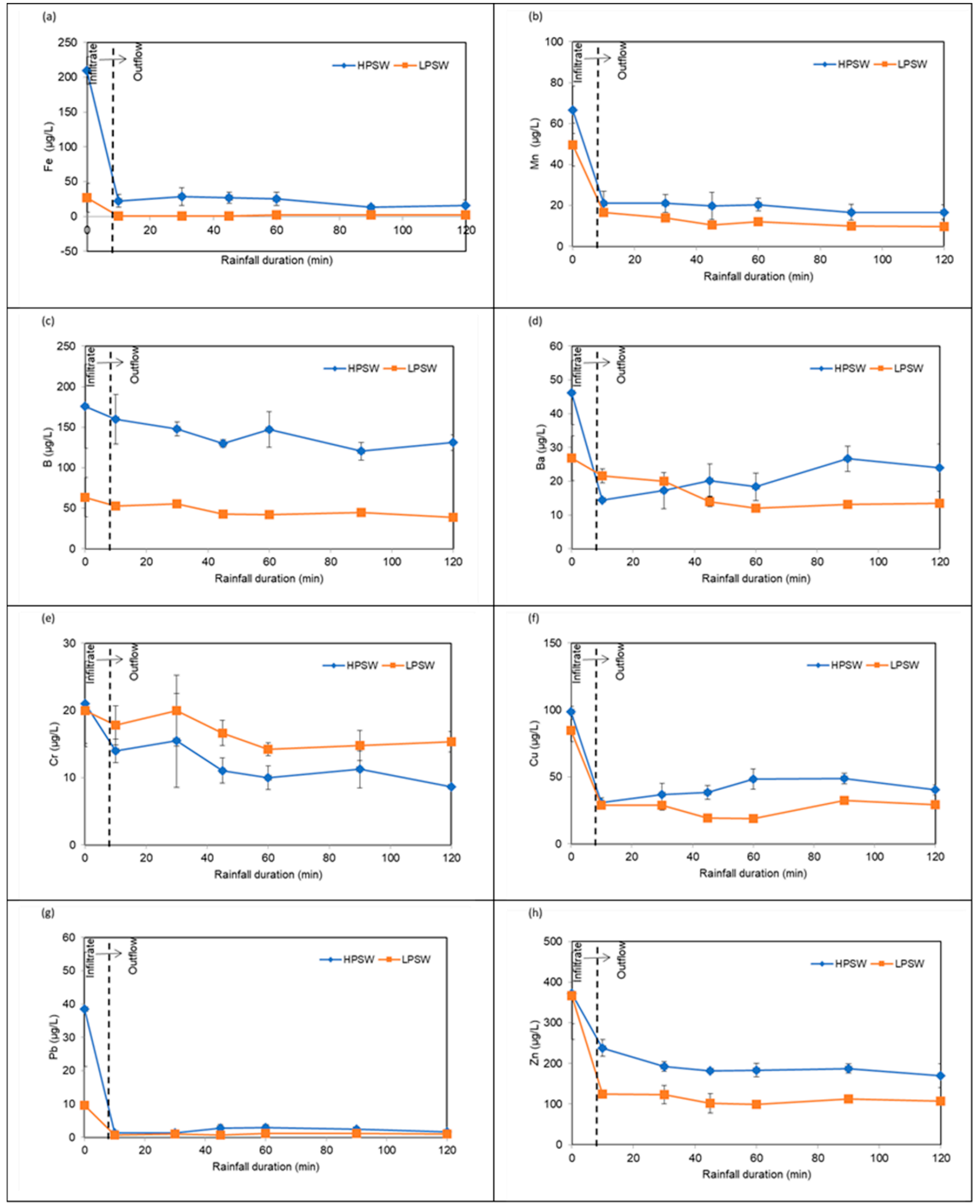

Figure 8. Variations of (a) Fe, (b) Mn, (c) B, (d) Ba, (e) $\mathrm{Cr}$, (f) $\mathrm{Cu},(\mathrm{g}) \mathrm{Pb}$ and (h) $\mathrm{Zn}$ before and after infiltration through permeable clay bricks. 

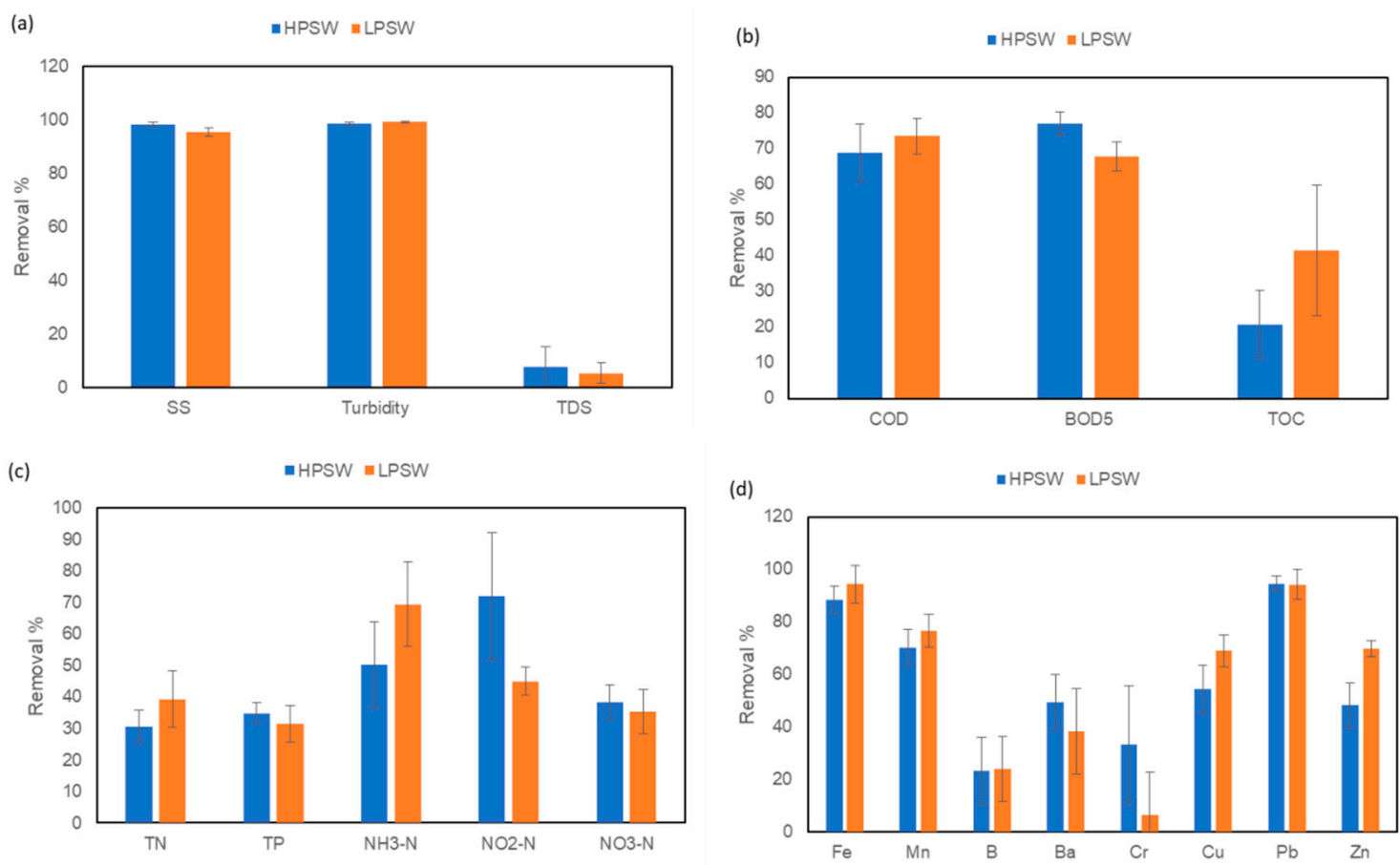

Figure 9. Removal efficiencies of (a) SS, turbidity and TDS, (b) organics, (c) nutrients, and (d) heavy metals from HPSW and LPSW after infiltration through permeable clay bricks.

\section{Discussion}

The effluent qualities of the SWs infiltrated through the clay bricks were assessed by comparing them with water quality standards for both drinking and reuse purposes. The performance of clay bricks in terms of pollutant removal efficacy was also compared with the previously studied LID technologies. Table 4 shows the comparison of effluent quality for both the HPSW and LPSW with national and international guidelines for various wastewater reuse applications [32-35]. The suitability of effluents was assessed for direct groundwater recharge by comparing the concentrations of the constituents with the drinking water quality standards, as the recharge water should be free from pollutants to avoid groundwater contamination. The effluents were also assessed for other reuse applications, such as unrestricted irrigation, fire protection, and toilet flushing.

In Table 4, pH, turbidity, TSS, and TDS in the HPSW and LPSW effluents were found well below the reuse standards. Organics (BOD5 and COD) also met the standard limits, achieving 8.7-14.1 and 11.1-29.6 mg/L in the effluents. Relatively lower concentrations of TN and TP were measured in the raw SWs, which were further decreased and found suitable for groundwater recharge and other reuse applications. The nitrogen components $\left(\mathrm{NH}_{3}-\mathrm{N}, \mathrm{NO}_{2}-\mathrm{N}\right.$, and $\left.\mathrm{NO}_{3}-\mathrm{N}\right)$ were also found under the limits in all observations. As presented in Table 4, heavy metals in the effluent were found below the limits for drinking and reuse standards. The concentration of Se $(32.3 \mu \mathrm{g} / \mathrm{L})$ in the influent HPSW was higher than the standards for both drinking water and reuse applications (see Table 3), which was $1.97 \mu \mathrm{g} / \mathrm{L}$, i.e., below the desired standard for both the drinking and reuse applications. Concentrations of $\mathrm{Pb}(38.5 \mu \mathrm{g} / \mathrm{L})$ in the HPSW were also found to be higher than the drinking water standard and reduced to less than $2.1 \mu \mathrm{g} / \mathrm{L}$ in the effluent.

The overall comparison of the influents showed that all heavy metals in both the HPSW and LPSW significantly reduced after infiltration from clay bricks, indicating the potential use of clay bricks to the permeable pavement system. The range of parameter concentrations in the effluents was always found within the reuse standards. Nevertheless, the presence of organics $\left(7-14.1 \mathrm{mg} / \mathrm{L} \mathrm{BOD}_{5}\right.$ and $\left.11.1-29.6 \mathrm{mg} / \mathrm{L} \mathrm{COD}\right)$ and bacteria in the effluents were found to be major concerns for groundwater recharge. Both organics and bacteria can cause microbial contamination in groundwater. A well-designed disinfection 
process, with careful monitoring and control of disinfection byproducts, is recommended for groundwater recharge.

Comparing the pollutants' removal capability of clay bricks with others LID technology in Table 4, it is evident that the clay bricks system is as efficient as bio-retention, grass swells, and sand filter systems. Therefore, the low-cost permeable clay bricks tested in the present study can be used as an effective LID technology. It is also important to disclose that the approximate cost of the clay bricks system was estimated to be as low as 50 USD/1000 bricks. Results suggest the use of clay bricks for constructing a more economically and environmentally sustainable permeable pavement system than the other available LID technologies. As the proposed system does not need additional processes and energy, it can be operated with minimum maintenance cost. As existing LID technologies require continuous runoff to perform effectively, the clay bricks-based pavement system would be a viable technology for arid and semi-arid regions with low annual rainfall.

Regarding potential applications, clay bricks are suitable for pavements serving light traffic, such as small cars, motorbikes, bicycles, and pedestrians. Generally, two-thirds of the urban and semi-urban areas are covered by impervious pavement surfaces. Replacing impervious surfaces with permeable pavements will not only improve the water quality and groundwater recharge but will also reduce load to the existing storm drainage system. There is a wide range of possible applications of the preamble bricks, for instance, house lawns, driveways, walkways, parking lots, sidewalks, and city streets. In most of the urban areas in the arid regions, including Saudi Arabia, the existing drainage infrastructure was designed and constructed for rainfalls of low intensity and durations. In the recent past, global climate change has caused several flash floods in the Gulf countries [42]. The proposed permeable clay bricks-based pavement system can minimize the flooding risk during the floods of longer (10-year or higher) return periods in the underdeveloped (Africa), developing (Asia), and economically emerging countries (Gulf) in arid and semiarid regions. The preamble clay bricks can reduce the pollution load on the recharged groundwater, which will reduce human health risk in rural and semi-urban areas of developing countries where shallow wells are common for drinking water supply. For the semi-tropical climate, some of the South Asian countries frequently experience highintensity and long-duration rainfalls. Most of these countries have unplanned and partially combined (with some SW allowance) drainage infrastructure. The permeable clay bricks pavement can delay the hydraulic load on the drainage system and minimize the flooding risk. The findings of the present research will help utility managers to plan more costeffective and sustainable LID technologies in the future.

\section{Conclusions}

This study evaluated the performances of porous clay bricks for runoff pollutant removal from the two different SWs. The performances of the brick layer were proven to be effective in removing pollutants from a diverse range of contaminated runoff. The permeable clay brick was highly effective (more than $98 \%$ ) in removing TSS and turbidity achieved from both HPSW and LPSW. BOD 5 and COD removal were achieved around $68-77 \%$ and $68-74 \%$, resulting in the production of higher quality water suitable for reuse and groundwater recharging applications. Poor to moderate removal of nutrients, $30.5 \%$ and $39.1 \%$ for $\mathrm{TN}$ and $34.7 \%$ and $31.3 \%$ for TP indicated the adsorptive removal of nutrients in the system. A significant amount of $\mathrm{NH}_{3}-\mathrm{N}(22.7 \%$ and $69.2 \%)$ and $\mathrm{NO}_{3}-\mathrm{N}(13.2 \%$ and $35.2 \%$ ) were reduced from HPSW and LPSW via the clay bricks. Heavy metals were also removed, ranging from $6.7 \%$ to $94 \%$ removal. Overall effluent water qualities for both HPSW and LPSW were comparable with other LID technologies and met the criteria for reuse applications. The study results indicated the pollutant removal efficiency of a permeable clay brick surface layer and provided a benchmark for the optimization of PPs design. The application of clay bricks to the appropriate design of the PPS pattern can remarkably improve SW drainage and the quality of the infiltrate. The findings of the present research will also help utility managers to plan more cost-effective and sustainable 
LID technologies in the future. A field investigation of a complete clay bricks pavement system with appropriate subsurface layers is recommended in future studies. Further study to investigate pollutant removal performances of the clay bricks under different rainfall intensities is also recommended.

Author Contributions: Conceptualization, M.S. and S.M.A.A.; Data curation, S.M.A.A., M.S. and H.H.; Formal analysis, S.M.A.A. and M.S.; Funding acquisition, M.S.; Investigation, S.M.A.A., F.A., M.A. and M.R.; Methodology, M.S., S.M.A.A. and M.A.; Project administration, M.S.; Resources, M.R.; Supervision, M.S.; Visualization, H.H. and M.R.; Writing-original draft, S.M.A.A. and M.S.; Writing-review and editing, H.H., M.R., F.A., M.A. and Y.E.-G. All the authors shared their expert opinion and indigenous knowledge for data curation and visualization. All authors have read and agreed to the published version of the manuscript.

Funding: This research was funded by the Deanship of Scientific Research, Qassim University, grant No. 10184-qec-2020-1-3-I.

Institutional Review Board Statement: Not applicable.

Informed Consent Statement: Not applicable.

Data Availability Statement: Not applicable.

Acknowledgments: The author(s) gratefully acknowledge Qassim University, represented by the Deanship of Scientific Research, for the financial support for this research under the number (10184qec-2020-1-3-I) during the academic year 1441 AH/2020 AD.

Conflicts of Interest: The authors declare no conflict of interest.

\section{References}

1. Davis, A.P.; Shokouhian, M.; Sharma, H.; Minami, C. Water quality improvement through bioretention media: Nitrogen and phosphorus removal. Water Environ. Res. 2006, 78, 284-293. [CrossRef] [PubMed]

2. Grebel, J.E.; Mohanty, S.K.; Torkelson, A.A.; Boehm, A.B.; Higgins, C.P.; Maxwell, R.M.; Nelson, K.L.; Sedlak, D.L. Engineered infiltration systems for urban stormwater reclamation. Environ. Eng. Sci. 2013, 30, 437-454. [CrossRef]

3. LeFevre, G.H.; Paus, K.H.; Natarajan, P.; Gulliver, J.S.; Novak, P.J.; Hozalski, R.M. Review of dissolved pollutants in urban storm water and their removal and fate in bioretention cells. J. Environ. Eng. 2015, 141, 4014050. [CrossRef]

4. Deblonde, T.; Cossu-Leguille, C.; Hartemann, P. Emerging pollutants in wastewater: A review of the literature. Int. J. Hyg. Environ. Health 2011, 214, 442-448. [CrossRef]

5. Yu, J.; Yu, H.; Xu, L. Performance evaluation of various stormwater best management practices. Environ. Sci. Pollut. Res. 2013, 20, 6160-6171. [CrossRef]

6. Reddy, K.R.; Xie, T.; Dastgheibi, S. Mixed-media filter system for removal of multiple contaminants from urban storm water: Large-scale laboratory testing. J. Hazard. Toxic. Radioact. Waste 2014, 18, 1-8. [CrossRef]

7. Anderson, B.S.; Phillips, B.M.; Voorhees, J.P.; Siegler, K.; Tjeerdema, R. Bioswales reduce contaminants associated with toxicity in urban storm water. Environ. Toxicol. Chem. 2016, 35, 3124-3134. [CrossRef] [PubMed]

8. LeFevre, G.H.; Hozalski, R.M.; Novak, P.J. The role of biodegradation in limiting the accumulation of petroleum hydrocarbons in raingarden soils. Water Res. 2012, 46, 6753-6762. [CrossRef]

9. Zhang, K.; Randelovic, A.; Page, D.; McCarthy, D.T.; Deletic, A. The validation of stormwater biofilters for micropollutant removal using in situ challenge tests. Ecol. Eng. 2014, 67, 1-10. [CrossRef]

10. USEPA, Green Infrastructure in the Semi-Arid West, Low-Impact Development and Green Infrastructure in the Semi-Arid West. Available online: https://www.epa.gov/green-infrastructure/green-infrastructure-semi-arid-west\#6 (accessed on 20 November 2020).

11. Sambito, M.; Severino, A.; Freni, G.; Neduzha, L. A Systematic Review of the Hydrological, Environmental and Durability Performance of Permeable Pavement Systems. Sustainability 2021, 13, 4509. [CrossRef]

12. Weiss, P.T.; Kayhanian, M.; Gulliver, J.S.; Khazanovich, L. Permeable pavement in northern North American urban areas: Research review and knowledge gaps. Int. J. Pavement Eng. 2019, 20, 143-162. [CrossRef]

13. Legret, M.; Colandini, V. Effects of a porous pavement with reservoir structure on runoff water: Water quality and fate of heavy metals. Water Sci. Technol. 1999, 39, 111-117. [CrossRef]

14. Roseen, R.M.; Ballestero, T.P.; Houle, J.J.; Briggs, J.F.; Houle, K.M. Water quality and hydrologic performance of a porous asphalt pavement as a storm-water treatment strategy in a cold climate. J. Environ. Eng. 2012, 138, 81-89. [CrossRef]

15. Yuan, X.; Tang, Y.; Li, Y.; Wang, Q.; Zuo, J.; Song, Z. Environmental and economic impacts assessment of concrete pavement brick and permeable brick production process- a case study in China. J. Clean. Prod. 2018, 171, 198-208. [CrossRef] 
16. Xie, N.; Akin, M.; Shi, X. Permeable concrete pavements: A review of environmental benefits and durability. J. Clean. Prod. 2019, 210, 1605-1621. [CrossRef]

17. Jiang, W.; Sha, A.; Xiao, J.; Li, Y.; Huang, Y. Experimental study on filtration effect and mechanism of pavement runoff in permeable asphalt pavement. Constr. Build. Mater. 2015, 100, 102-110. [CrossRef]

18. Niu, Z.G.; Lv, Z.W.; Zhang, Y.; Cui, Z.Z. Stormwater infiltration and surface runoff pollution reduction performance of permeable pavement layers. Environ. Sci. Pollut. Res. 2016, 23, 2576-2587. [CrossRef]

19. Li, H.; Li, Z.; Zhang, X.; Li, Z.; Liu, D.; Li, T.; Zhang, Z. The effect of different surface materials on runoff quality in permeable pavement systems. Environ. Sci. Pollut. Res. 2017, 24, 21103-21110. [CrossRef]

20. Zhang, K.; Yong, F.; McCarthy, D.T.; Deletic, A. Predicting long term removal of heavy metals from porous pavements for stormwater treatment. Water Res. 2018, 142, 236-245. [CrossRef]

21. Drake, J.A.P.; Bradford, A.; Marsalek, J. Review of environmental performance of permeable pavement systems: State of the knowledge. Water Qual. Res. J. 2013, 48, 203-222. [CrossRef]

22. Brown, C.; Chu, A.; Duin, B.; Valeo, C. Characteristics of sediment removal in two types of permeable pavement. Water Qual. Res. J. Can. 2009, 44, 59-70. [CrossRef]

23. Liu, J.; Yan, H.; Liao, Z.; Zhang, K.; Schmidt, A.R.; Tao, T. Laboratory analysis on the surface runoff pollution reduction performance of permeable pavements. Sci. Total. Environ. 2019, 691, 1-8. [CrossRef]

24. Zhang, Z.; Li, Z.; Zhang, X.; Liu, D.; Li, Z.; Li, H. Systematically investigated the influences of permeable pavement materials on the water quality of runoff: Batch and column experiments. Water Air Soil Pollut. 2018, 229, 155. [CrossRef]

25. Yu, Z.; Gan, H.; Xiao, M.; Huang, B.; Zhu, D.Z.; Zhang, Z.; Wang, H.; Lin, Y.; Hou, Y.; Peng, S.; et al. Performance of permeable pavement systems on stormwater permeability and pollutant removal. Environ. Sci. Pollut. Res. 2021, 28, 28571-28584. [CrossRef]

26. Schlea, D.; Martin, J.F.; Ward, A.D.; Brown, L.C.; Suter, S.A. Performanceand water table responses of retrofit rain gardens. J. Hydrol. Eng. 2014, 19, 05014002. [CrossRef]

27. Lin, Z.; Yang, H.; Chen, H.; Ouyang, X.; Li, Z. Comparison of the decontamination performance of three permeable bricks: Adsorption and filtration experiments. Pol. J. Environ. Stud. 2020, 29, 3225-3233. [CrossRef]

28. Han, S.; Yang, Y.; Liu, S.; Lu, M. Decontamination performance and cleaning characteristics of three common used paved permeable bricks. Environ. Sci. Pollut. Res. 2020, 28, 15114-15122. [CrossRef]

29. Alharbi, F.; Almoshaogeh, M.; Shafiquzzaman, M.; Haider, H.; Rafiquzzaman, M.; Alragi, A.; ElKholy, S.; Bayoumi, E.A.; EL-Ghoul, Y. Development of Rice Bran Mixed Porous Clay Bricks for Permeable Pavements: A Sustainable LID Technique for Arid Regions. Sustainability 2021, 13, 1443. [CrossRef]

30. Al-Amri, N.; Subyani, A.M. Generation of Rainfall Intensity Duration Frequency (IDF) Curves for Ungauged Sites in Arid Region. Earth Syst. Environ. 2017, 1, 8. [CrossRef]

31. Alotaibi, K.; Ghumman, A.R.; Haider, H.; Ghazaw, Y.M.; Shafiquzzaman, M. Future Predictions of Rainfall and Temperature Using GCM and ANN for Arid Regions: A Case Study for the Qassim Region, Saudi Arabia. Water 2018, 10, 1260. [CrossRef]

32. APHA. Standard Methods for the Examination of Water and Wastewater, 21st ed.; American Public Health Association: Washington, DC, USA, 2005

33. MWE. Technical Guidelines for the Use of Treated Sanitary Wastewater in Irrigation for Landscaping and Agricultural Irrigation; Ministry of Water and Electricity: Riyadh, Saudi Arabia, 2006.

34. World Health Organization (WHO). Guidelines for the Safe Use of Wastewater, Excreta and Greywater, Volume 4: Excreta and Greywater Use in Agriculture; WHO: Geneva, Switzerland, 2006.

35. World Health Organization (WHO). Guidelines for Drinking Water Quality, 2nd ed.; World Health Organization: Geneva, Switzerland, 2004

36. Saudi Arabian Standards Organization (SASO). Un-Bottled Drinking Water. SASO 701 and mkg 149 (In Arabic); SASO: Riyadh, Saudi Arabia, 2000.

37. Ogunmodede, O.T.; Adebayo, O.L.; Ojo, A.A. Enhancing adsorption capacity of clay and application in dye removal from wastewater. Int. Lett. Chem. Phys. Astron. 2014, 39, 35-51. [CrossRef]

38. Song, R.; Gong, Y.; Li, J.; Li, X. Progress in controlling urban nonpoint source pollution bypermeable pavement. Environ. Sci. Technol. 2014, 37, 57-63.

39. Soetardji, J.P.; Claudia, J.C.; Ju, Y.H.; Hriljac, J.A.; Chen, T.Y.; Soetaredjo, F.E.; Ismadji, S. Ammonia removal from water using sodium hydroxide modified zeolite mordenite. RSC Adv. 2014, 5, 83689-83699. [CrossRef]

40. Uddin, M.K. A review on the adsorption of heavy metals by clay minerals, with special focus on the past decade. Chem. Eng. J. 2017, 308, 438-462. [CrossRef]

41. Veli, S.; Alyüz, B. Adsorption of copper and zinc from aqueous solutions by using natural clay. J. Hazard. Mater. 2007, 149, 226-233. [CrossRef]

42. Ahiablame, L.M.; Engel, B.A.; Chaubey, I. Effectiveness of low impact development practices: Literature review and suggestions for future research. Water Air Soil Pollut. 2012, 223, 4253-4273. [CrossRef]

43. Zarezadeh, V.; Lung, T.; Dorman, T.; Shipley, H.T.; Giacomoni, M. Assessing the performance of sand filter basins in treating urban stormwater runoff. Environ. Monit. Assess. 2018, 190, 697. [CrossRef] 